Scientific Journal Warsaw University of Life Sciences - SGGW

Problems of World Agriculture volume 17 (XXXII), number 4, 2017: 52-67

DOI: $10.22630 /$ PRS.2017.17.4.81

Marta Domagalska-Grędys ${ }^{1}$

University of Agriculture in Krakow

\title{
Relational Premises in the Cooperation Between Farms with Conservative Breeds and Industry Organisations ${ }^{2}$
}

\begin{abstract}
The main aim of the study was to indicate relational premises in the cooperation between industry organisations and farms with conservative breeds (cattle, pigs, and sheep). It has been assumed that the processes of integration of domestic animal breeders depend on the state of the relationships established (in terms of quality, sustainability, dependence and uniqueness) with industry organisations. The research was carried out on the basis of an interview questionnaire (in 2017) with farmers from south-eastern Poland, representatives of organisations, and a review of secondary sources describing the activities of industry organisations since the beginning of their existence. The specificity of the entities under analysis stems from their role and responsibilities. Breeders contribute to the growth of biodiversity, while industry organisations are an important partner in their relationships as they support farms (they mediate in the contracting process, organise trainings, represent the interests of producers in Poland and abroad). Preliminary results of the research indicate that the best conditions for cooperation are in the networks of breeders of conservative breeds of pigs as well as in interorganisational relationships with the 'POLSUS' industry organisation.
\end{abstract}

Key words: network relationships, producers and breeders of conservative breeds, industry organisations

JEL Classification: Q13, P48, O43

\section{Introduction}

The study of human relationships as well as economic relationships is based on the network theory. We treat our interactions as a source of satisfying our needs and creating added value. ${ }^{3}$ The benefits of developing interorganisational relationships include an increase in knowledge and innovativeness (Cygler, 2002, 2007, p. 17; Czakon, 2007, p. 248; Krzyżanowski, 1999, p. 165; Latusek-Jurczak, 2011, p. 19 and others). Creating inter-organisational relationships and bonds grants access to resources, resulting in faster development and higher levels of efficiency (Lorenzoni, Lippari, 1999, p. 317-338).

As relationships provide numerous desirable benefits, they can be perceived as valuable assets, and, therefore, should be monitored. This is because there is a real possibility of multiplying or losing the benefits of the relationships.

Modern agriculture has many models of production, from traditional (ecological) to sustainable, to industrial or high-tech. Due to the changing levels of biodiversity and consumer preferences (an increase in awareness and wealth), animal production is carried

\footnotetext{
${ }^{1} \mathrm{PhD}$, associated professor, Department of Management and Marketing of Enterprises, Institute of Economics and Business Management, University of Agriculture in Krakow, Al. Mickiewicza 21, 33-100 Kraków,

e-mail: rrdomaga@cyf-kr.edu.pl

2 The publication concerns the BIOSTRATEG2 / 297267/14 / NCBR / 2016 project, funded by the National Center for Research and Development under the Biostrateg program entitled 'Directions for the Use and Conservation of Livestock Genetic Resources in the Conditions of Sustainable Development'.

${ }^{3}$ This generally concerns economic benefits from the relationships in which the examined entities take part.
} 
out in new conditions of integration (and globalization). A closer look reveals that producers (breeders) and industry organisations fulfil new functions. The history of industry organisations repeatedly confirms that the process of adaptation to the changing socio-political conditions is ongoing. The new context for perceiving the role of industry organisations as associations implementing the biodiversity Programme raises the question as to what extent they are ready to fulfil the new role and support farms? Do relationships developed between them give hope of development of farms through a network of relationship of cooperation?

The main objective of the study was to indicate relational premises in the cooperation between industry organisations and farms with conservative breeds (cattle, pigs, and sheep). The specific objectives included:

1. Description of the involvement of industry organisations in actions supporting member producers and breeders.

2. Assessment of the relations between farmers and industry organisations in terms of quality, sustainability, dependence and uniqueness.

3. Opinions on "good relations" of cooperating farmers and organisations (what is a good relation?).

The following research questions were posed: Do farmers and industry organisations rate the relations similarly? In which cases are the relations (between farmer and institution) the most harmonious? Which relation quality characteristics can be considered satisfactory and which require improvement (due to a low rating)?

The subject of the study was the farms with animals of conservative breeds and the best organised industry organisations of the supra-local nature, with which they established formal relationships. The specificity of the farms results from their role and responsibilities. By maintaining the breeds of protected animals, breeders commit themselves to complying with certain procedures and, thus, increasing biodiversity. Breeders establish formal relationships with various institutions, including, apart from the aforementioned industry organisations, the National Research Institute of Animal Production in Balice (the coordinator and implementer of the protection of farm animals ${ }^{4}$ ), the Agency for Restructuring and Modernization of Agriculture (ARMA) ${ }^{5}$ (which transfers subsidies to livestock units covered by the biodiversity protection Programme), the Agricultural Advisory Centre, Veterinary Inspection, banks, municipal offices, universities, feed suppliers, and customers.

Industry organisations participate in activities which support farmers and processes of transformation in agriculture by influencing the state agricultural policy, amending the legislation, representing their interests in the European institutions (in Brussels) and global organisations (IHAR), and providing services (issuing certificates for breeding animals) (Grzybek, 2003, p. 32; Halamska, 2006, p. 35; Kawa, Grzybek ,2009, p. 128;

4 The National Research Institute of Animal Production in Balice determines the criteria, thresholds and the number of animals which indicate that breeds are endangered; it establishes the program for the protection of endangered breeds; it supervises the implementation of and coordinates programs for the conservation of genetic resources. Downloaded: 7 October 2017, from:

http://www.arimr.gov.pl/fileadmin/pliki/PB_2015/WPRE/03_03_2017/PRSK_2017_Pakiet_7.pdf.

5 The Agency for Restructuring and Modernization of Agriculture (ARMA) plays its role at the beginning of the process of applying for co-financing of farms. The applications for the first and subsequent agri-environmental payments are submitted with the head of the Agency's Poviat Office, competent for the farmer's place of residence or registered office, within the deadline set for submitting applications under the direct support schemes. 
Kołodziejczyk, Milczarek-Andrzejewska，Śpiewak，2015，p. 67; Miś, 2008， p. 60; Wasilewski, 2005, p. 9; Wójtowicz-Dawid, 2011, p. 335). It should be mentioned that in the present economic conditions, industry organisations are becoming involved in the process of improving the institutional system. The improvement of the institutional environment in which farms with animals of conservative breeds operate, is achieved by various means, such as: replacing ineffective institutions with more effective ones, experimenting in the area of institution building and allowing institutions to compete on the regional, national and transnational level (Wilkin, 2003, p. 50). Industry organisations enter the path of building an institutional order aimed at EU socio-economic cohesion and the harmonization of legal standards (Woźniak, 2009, p. 9).

The interest in the relationships established between farms with conservative breeds and industry organisations stems from the needs of both practice and theory. This is, among others, the continuation of the author's research on the relationships among groups of agricultural producers (GAP). The attempt made to determine the conditions for creating high-quality cooperation ${ }^{6}$ filled the cognitive gap in the area of relational variables responsible for biodiversity development with the participation of breeders of conservative breeds, and industry organisations.

\section{Theoretical justification for the analysis of relationships in network- based structures}

The study of network relationships can be explained by different theories. One of the most significant is the theory of transaction costs (TC). R.H.Coase (1988), the author of the transaction costs put forward a hypothesis that the networks appear in response to the constraints of the mechanisms for the coordination of business activity (of the market and enterprise). Subsequently, W.W. Powell (1990) modified the assumptions of the TC theory by pointing to the network as a separate form of coordination. From the point of view of the analysis of the functioning of organisational networks, contractual theories are of great importance, as they analyse the contents of the 'black box', including: property rights, information asymmetry, resource specifics, limited rationality, contract incompleteness, power, opportunism or the risk of abuse. Referring to information asymmetry, S. Balakrishnan and M. Koza (1993, p. 99-117) emphasise that the organisation that has the information has more bargaining power, which makes the relationship asymmetrical.

Contract orientation modified the perception of the enterprise (the nexus of contracts became the subject of analysis), but it also allowed for the formulation of any problem in terms of the contract, and, consequently, made its analysis possible through the prism of transaction costs (Williamsom, 1998). The theory of property rights, which is focused on specific contractual relationships with asymmetric position of the parties participating in the contracts, also carries a cognitive value. Identifying and analysing this asymmetry also extends the cognitive value of the research on relationships, transferring them to the realms of the agency dilemma (Arrow, 1985).

\footnotetext{
${ }^{6}$ Selected results of the research are presented, among others, in the publication of M. Domagalska-Grędys (2016).
} 


\section{The data and methods}

The analysis of the relationships between farms and organisations was carried out with due regard of the historical background of industry organisations (the review of the literature) and own research, embedding the information obtained in the new economic reality (the implementation of agri-environmental Programmes). The opinions of farmers and employees of industry organisations in the context of the official declarations made by the organisations (based on their statute or descriptions on their websites) were of great importance. The aim was to objectively present the greatest amount of information which confirms the involvement of the institutions in resolving problems of farmers, or breeders of conservative breeds.

The testing instrument was a questionnaire of an interview, carried out by employees of the Agricultural Advisory Centre and the author with farms and representatives of organisations. The research was carried out in deliberately selected entities (farms ${ }^{7}$ having the appropriate number of animals of conservative breeds) and the professional organisations of which the farms were members. The literature review and secondary data from the websites were used to analyse the industry organisations and their roles. The area of the research on farms included the provinces of south-eastern Poland (Małopolskie, Podkarpackie and Lubelskie). The research was conducted from June to September 2017.

The research task was to determine the state of the relationships (based on the characteristics $^{8}$ ) that can affect agricultural producers (breeders) integration processes. It was assumed that integration processes depend on the state of the relationship (quality, sustainability, dependence) between participants. The focus was not on dependence (power) as such, but on the conditions of creating such dependencies, which were examined based on literature on network relations and selected results of own research ${ }^{9}$.

The network approach, applied in the paper, resulted from highlighting the contacts between farms and industry organisations. The scope of the network environment was considered from the perspective of an individual farm, which, by joining the industry organisation, extends its network of connections with the environment. The identification of network relationships in the conventionally accepted network was based on three distinctive features, proposed by Milena Ratajczak-Mrozek (2009, p. 89), namely: continuity of interactions, interdependence and infinity.

\footnotetext{
7 Approx. 100 farms and 30 cooperating institutions in the entire research trial. For the purposes of this publication, we used representatives of the farms with most influential conservative breeds: cattle, pigs and sheep of three industry organizations of which they were members. These are the preliminary results of the study.

${ }^{8}$ The selection of characteristics for relation assessment modelled on studies of the authors quoted in the paper, concerning the relations in networks of companies carrying out business activity in Poland and abroad.

${ }^{9}$ The selection of characteristics for the assessment of relationships was based on the research of relationships in the networks of enterprises conducting business activity in Poland and abroad, carried out by the authors, cited in this study.
} 


\section{The findings of the research}

\section{The scope of protection of biodiversity in livestock production (the outline of the history of protection and selected legal aspects)}

In 1996, Poland officially joined the implementation of FAO's Global Strategy for the Conservation of Animal Genetic Resources. The Minister of Agriculture established the National Coordinating Centre for the Conservation of Animal Genetic Resources, which initially operated within the Central Animal Breeding Station, and in 2002, it became part of the National Research Institute of Animal Production. In 1999, the work on the National Programme for the Protection of Animal Genetic Resources was undertaken. On this basis, in 1999, the Minister of Agriculture and Rural Development approved 32 Programmes for the protection of genetic resources, which included 75 breeds, varieties and families of farm animals, including fish (Krupiński, 2008, p. 3).

In June 2001, the Minister of Agriculture and Rural Development declared Poland's participation in the FAO-initiated process of preparation of the World Livestock Genetic Resources Report, joined by 169 countries.

In line with the FAO guidelines, the report included an assessment of the status of agricultural biodiversity in the livestock sector along with a review of production systems and assessment of the state of use of the genetic resources ${ }^{10}$.

The protection of animals of conservative breeds was announced, among others, by the ordinance of the Ministry of Agriculture and Rural Development of 13 March 2013, item 361 on detailed conditions and procedures for granting financial aid within the 'Agrienvironmental Programme', covered by the Rural Development Programme for the years 2007-2013. Package 7 of the ordinance includes the statement on conservation of endangered genetic resources of animals in agriculture. In turn, the ordinance of 18 March 2015 stipulates the detailed conditions and procedures for granting financial aid within the 'Agri-environmental and Climatic Measure' of the Rural Development Programme for the following years (2014-2020) ${ }^{11}$.

The agri-environmental payment is granted for cows, mares, sows or sheep mothers, with a minimum number of 4 cows, 5 sheep mothers of the Olkuska breed, 15 sheep mothers of the cakiel podhalański breed and 10 sows of the Puławska breed.

Package 7 entitled "The Conservation of Endangered Genetic Resources of Animals in Agriculture" specifically defined races, subject to protection. For cattle, they include the following breeds: Polish red, white-backed, Polish red-and-white and black-and-white; for sheep, they include the following breeds: Wrzosowka sheep, Swiniarka sheep, Olkuska sheep, colored Polish mountain sheep, colored merino sheep, Uhruska sheep, Wielkopolska sheep, żelaznienska sheep, Korideil sheep, Kamieniecka sheep, Pomorska sheep, cakiel podhalański sheep, old-type Polish merino sheep; for pigs: Puławska, Złotnicka white pig and złotnicka spotted pig.

\footnotetext{
${ }^{10}$ The remaining elements of the FAO document as well as the elaboration on ten priority areas of activities can be found in the cited publication by J. Krupiński (2008).

${ }^{11}$ http://www.arimr.gov.pl/fileadmin/pliki/PB_2015/WPRE/16_03_2017/D20150415.pdf; Downloaded: 7 October 2017.
} 
The aforementioned ordinances (of 2013 and 2015) brought consequences for producers, including: fees and penalties for non-compliance, but also the need to contact various institutions. It leads to the establishment of numerous formal relationships (with The Agency for Restructuring and Modernization of Agriculture (ARMA), National Research Institute of Animal Production in Balice, Veterinary Inspection, Commune Offices) and informal connections (with other farmers).

\section{The role of industry organisations in establishing relationships (legal basis)}

Agricultural industry organisations operate on the basis of the Law of 8 October 1982 on socio-professional organisations of farmers ${ }^{12}$. As stated by A. Sikorska-Lewandowska (2016, p. 164), the law has been amended several times. According to Article 23 of the Law, agricultural industry organisations constitute voluntary, independent and selfgoverning socio-professional organisations, representing and defending the rights and interests of individual farmers specializing in a particular branch of plant or animal production. The cited law provides the rights of industry associations which determine the adaptation of the organisation to the new political conditions, formed as a result of the economic changes which occurred after 1989 and, subsequently, as a result of Poland's accession to the European Union. The basic rights and obligations of industry organisations are the following: submission of expert opinions to relevant bodies, filing motions, postulates and demands, initiation of legal regulations and participation in negotiations relating to consultations on legal acts. The consultation takes place through sending draft legal documents, project assumptions, plans and invitations to participate in developing documents, holding joint meetings, consultations and negotiations. The competent authorities are obliged to comment on the opinions, motions and postulates submitted by the agricultural industry organisations within one month. An industry organisation can represent its members as a proxy when negotiating contractual terms and conditions, contracts for the supply of the means of production, plant protection products, and it can act as the supervisor of the implementation of the contracts.

Industry organisations are established at different levels of territorial division of the country, which means that they have a different spatial range of activity: area, district, region, province, and the entire country. One of the best organised groups are pig farmers (apart from beekeepers and sugar beet producers), producers of cattle and milk, and producers of sheep and goats (Halamska, 2008, p.118).

\section{The examples of industry organisations bringing together breeders and animal producers in Poland}

The achievements of agricultural organisations in Poland are connected with the existence of the law which was introduced more than 30 years ago, and historically, they go

${ }^{12}$ The Act of 8 October 1982 on socio-professional farmers' organizations, Dziennik Ustaw 1982, No. 32, item 217 
back to the period of the Partitions of Poland ${ }^{13}$. Socio-professional farmers' organisations play an important role, along with agriculture chambers, agricultural industry organisations and producer organisations, in representing the interests of farmers before the State and local government administration (Sikorska-Lewandowska, 2016, p. 175). Due to the aim of the research as well as a very large target group of all industry organisations, the focus was made on three of them (PFHBiPM, POLSUS and PZOw), representing breeders of conservative breeds of cattle, pigs and sheep in south-eastern Poland.

\section{POLSUS}

The origins of POLSUS date back to 1958, when the first National Assembly of Delegates of province unions of producers of breeds of pigs, suitable for the manufacture of bacon and ham, was held in Warsaw. The activities of the association were focused on a number of issues, including training and instruction activities, the protection of the interests of producers, and cooperation with individuals and organisations working for the benefit of agriculture.

The history of POLSUS includes four periods, namely: 1 . The preintegration period (1958-1973), in which the Union, having a legal personality, was involved in intensive activities with full autonomy; 2. The integration period (1974-1980), when the Union was incorporated into the Central Union of Agricultural Circles, and, thus, deprived of a legal personality; consequently, its work was made dependent on administrative decisions; 3 . The renewal period (1981-2003), in which the Union regained its legal personality and once again became a self-governing and independent organisation. In 1981, a new statute was adopted at the $7^{\text {th }}$ National General Congress of Delegates of the province associations. The statute changed the previous name of the Association of Producers of Pigs to the Polish Association of Breeders and Producers of Pigs, and the abbreviation 'POLSUS' was selected through the competition process (in 1989). 4. Since 1 April 2003, ... the Polish Union of Breeders and Producers of Pigs 'POLSUS' took over from the National Centre for Animal Breeding, the tasks of pig breeding in Poland on the basis of a permit issued by the Ministry of Agriculture and Rural Development.

The 45-year period of the Association/Union's activity was marred by diverse sociopolitical conditions of the country, which had a clear impact on its work.

The main objective of the Association's activity was to 'defend the interests of pig producers', and, after 1 April 2004, also to defend the interests of breeders. While in the initial period of the union's work, the protection of interests was expressed mainly in the supervision of standardization in meat processing plants, the control at purchase points and in the sphere of the supply of feed and veterinary medicines, since 1982, the Union has been involved in shaping agricultural and social policy. Changes of the transformation period, the privatization of meat processing plants, have changed the perspective of the activities carried out by POLSUS. The union assumed, among others, matters related to breeding. On 10 December 2003, the Main Board of the Polish Union of Breeders and Producers of Pigs 'POLSUS' admitted to the ranks of the Union, organisations of breeders affiliated to the Polish Federation of Breeders of Breeding Pigs with its seat in Poznań. The 'POLSUS' organisation undertook new tasks which included, among others, assuming

\footnotetext{
${ }^{13}$ The first farmers' circles were established in the Polish lands in the 19th century.
} 
breeding activities throughout Poland from the National Centre for Animal Breeding/ Regional Centre for Animal Breeding in April 2003, establishing cooperation with breeders who had previously belonged to various organisations. Earlier, i.e. until May 2003, breeders had practically no influence on the shape of breeding in Poland. Currently, 'POLSUS' operates in four districts ${ }^{14}: 1$. Northern District with its registered office in Bydgoszcz (with branches in Bydgoszcz, Gdańsk, Olsztyn and Koszalin); 2. Central District with its registered office in Warsaw (with branches in Warsaw, Białystok and Łódź); 3. Western District with its registered office in Poznań (with branches in Poznań, Opole, Wrocław and Zielona Góra); 4. Eastern District with its registered office in Lublin (with branches in Lublin, Kielce, Rzeszów and Krakow).

The cooperation between POLSUS and other entities consists in:

1. Implementation of the objectives of the National Breeding Programme with research institutes.

2. Measures aimed at stabilizing the market of pigs with the Online Slaughter Pigs Exchange Platform called e-WGT, under the auspices of the Minister of Agriculture and Rural Development. The establishment of e-WGT is the result of an agreement concluded between 'POLSUS', the National Council of Agricultural Chambers and the e-WGT Company.

3. Cooperation with the Modern Farmer Portal called 'farmer.pl'.

'POLSUS' undertakes initiatives to stabilize and protect the market of pigs. It carries out promotional and information activities supporting the pig breeding and raising sector. It cooperates with numerous industry organisations and R\&D units.

Within these activities, PQS (Pork Quality System) was created with the participation of 'POLSUS' as the co-author and co-owner. In 2009, the Minister of Agriculture and Rural Development recognized PQS as the national food quality system.

'POLSUS' is a partner in the cooperation programme with the AUCHAN retail chain in the field of the production of pork from pigs of the Puławska breed and cooperates with the National Rural Development Network (NRDN) of the Lubelskie Province.

As part of the individual cooperation or as a member of the consortium, it also participates in national and international research projects (e.g. Q-PorkChains, EconWelfare, or POIG).

Due to the funds from the Meat Pork Promotion Fund, it implements a number of valuable and attractive projects. Every year, it organises breeding animals exhibitions, promoting breeding stock. The financial means of the Meat Pork Promotion Fund served to establish the 'Strategy for Reconstruction and Development of Pork Production in Poland through 2030', which contains a set of guidelines for the sector; the implementation of the guidelines would improve the situation in the pig sector. Also, the data on the dietary value of pork was updated, and dissemination of the results allows the reputation of pork as fat and unhealthy meat to be changed. With the participation of a law firm, training was organised for farmers in the scope of obtaining permits for the construction or extension of pig farms.

The cooperation with the Foundation of Assistance Programmes for Agriculture (FAPA) made the organisation of training courses for farmers in the field of high quality meat production possible.

\footnotetext{
${ }^{14}$ http://www.polsus.pl/kontakt/filie
} 


\section{PFHBiPM - The Polish Federation of Cattle Breeders and Dairy Producers}

The Polish Federation of Cattle Breeders and Dairy Producers in Warsaw is the only legitimate representative of cattle and dairy producers in Poland. It was established in 1995. It is an independent, voluntary and self-governing organisation bringing together more than 11,000 members gathered in eleven regional and breeding organisations ${ }^{15}$. These are individual farmers, state-owned farms, state-owned and private companies, co-operative and leased farms. Since 1 July 2006, the Polish Federation has had its representation in all the provinces in the country. It is a member of the International Committee for Animal Recording (ICAR), the World Holstein Friesian Federation (WHFF) and the European Holstein and Red Holstein Confederation (EHRC). On 1 July 2004, the Polish Federation of Cattle Breeders and Dairy Producers in Warsaw became the only entity authorized by the Minister of Agriculture and Rural Development in Poland to keep flock books for dairy cattle breeds. On 1 July 2006, the Polish Federation of Cattle Breeders and Dairy Producers in Warsaw assumed the task of evaluating cattle performance. The Ordinance of the Ministry of Agriculture and Rural Development of 30 November 2010, describes in detail the responsibilities of the PFHBiPM. Article 7, section 1, points 1-6 and 10 of the Law on the Organisation of Livestock Breeding and Reproduction establishes the principles for carrying out the evaluation of performance. On 1 July 2007, the Polish Federation of Cattle Breeders and Dairy Producers in Warsaw assumed the tasks of evaluating the type and structure of first-calf heifers and dairy cows.

The purpose of PFHBiPM is to represent interests and defend the rights of its members, in particular, through:

- taking strategic actions connected with cattle breeding and dairy production;

- supporting cattle breeding and dairy production;

- undertaking supra-regional or nationwide tasks in cattle breeding and dairy production;

- adopting breeding Programmes and coordinate their implementation;

- helping members of the organisation with their statutory activities;

- representing PFHBiPM on the international arena;

- interacting with international organisations dealing with issues related to the evaluation of cattle performance, insemination and breeding.

- cooperating closely with national organisations and institutions dealing with the insemination of cattle;

- promoting the good reputation of Polish cattle breeders through:

- carrying out evaluations of the performance of breeding value of cattle of dairy breeds as well as meat and dairy breeds,

- keeping cattle flock books and breeding documentation in accordance with the existing regulations,

- running milk evaluation laboratories,

\footnotetext{
${ }^{15}$ Regional branches of PFHBiPM are represented by: 1. Białystok with the registered office in Jeżew Stary, 2. Bydgoszcz with the registered office in Minikowo, 3. Gdańsk, 4. Gostyń, 5. Koszalin, 6. Lublin; 7. Łódź with the registered office in Rzgów, 8. Olsztyn with the registered office in Dorotowo, 9. Poznań, 10. Wrocław, 11. Zabierzów near Kraków.
} 
- publishing results of the evaluation of the performance or breeding value of cattle,

- maintaining an IT system for the needs of evaluation of the performance and breeding value of cattle,

- conducting specialized vocational trainings for persons conducting the evaluation of performance, and issuing appropriate certificates in this field,

- organising activities ensuring the implementation of modern methods in the field of cattle breeding and dairy production,

- developing and implementing regional and national breeding Programmes,

- organising exhibitions, shows and seminars,

- carrying out the selection in the herd subjected to evaluation, giving recommendations regarding herd replacement, selective breeding and cattle classification at the request of breeders,

- utilizing grants for biological progress in the Programmes approved by the Ministry of Agriculture and Rural Development,

- conducting trade and service activities in the field of milk quality assessment,

- conducting an evaluation of milk for breeding purposes,

- providing advisory and training services.

\section{PZOw - The Polish Sheep Breeders' Association and its regional branches}

The Polish Sheep Breeders' Association (PZOw) is a voluntary, independent and selfgoverning, socio-professional organisation representing and defending the rights and interests of the Regional Sheep and Goat Breeder Associations and other organisations promoting the breeding and raising of sheep and goats. The Polish Sheep Breeders' Association acts on the basis of the provisions of the Act of 8 October 1982 on social and professional organisations of farmers (Polish Journal of Laws "Dziennik Ustaw", No. 32, item 217) and the Ordinance of the Minister of Agriculture and Rural Development concerning the entrustment of the matters of breeding sheep and goats to the Polish Sheep Breeders' Association.

The Polish Sheep Breeders' Association gathers 11 regional associations, covering the entire territory of the country. Regional Associations work directly with sheep and goat breeders. They carry out the evaluation of sheep and goats in flocks as well as make entries on the animals of these species in the flock books.

The Polish Sheep Breeders' Association was established on 20 January 1958 at the 1st General Assembly. Shortly after, the statutes of the Province Associations of Sheep Breeders were developed and approved. The key moment for the Polish Sheep Breeders Association and the whole of the sheep industry was the National Council of Sheep Industry Workers, held between 11-13 December 1958 in Zakopane. It was attended by representatives of science, the system of sheep assembly centres, textile industry, and sheep breeders. It was pointed out that the existence of sheep breeders' associations, whose main tasks were the improvement of domestic sheep breeding and organising sheep production, is useful. The main directions of activity, in which sheep industry was perceived as an integrated whole, have been determined. 
The period between 1958-1969 marked an intensive development of sheep production. In the subsequent years, the Association organised the Teams of Shearers and the National Training Centre for Shearers. In 1973, in Poznan, the National Shearing Contest was organised with the participation of foreign shearers. This was the first international shearing contest in Europe. The period of 1974-1980 brought further integration around the Central Association of Agricultural Circles and the loss of independence of the unions. This resulted in the departure of a large part of experienced zootechnical staff working in the sheep industry. The years 1981-1983 resulted in the regaining of full self-management by sheep breeders' associations. Organisational and self-government structures were rebuilt. In 1982, the association has begun to activate the production of livestock for export purposes.

Table 1. Information on selected industry organisations

\begin{tabular}{|c|c|c|c|}
\hline Specification & POLSUS & PFHBiPM & PZOw \\
\hline $\begin{array}{l}\text { Year of } \\
\text { establishment }\end{array}$ & 1958 & 1995 & 1958 \\
\hline $\begin{array}{l}\text { Geographical } \\
\text { reach }\end{array}$ & $\begin{array}{l}4 \text { districts } \\
13 \text { regional unions of producers } \\
\text { and breeders }\end{array}$ & All provinces in Poland & 11 regional branches \\
\hline $\begin{array}{l}\text { Number of } \\
\text { members }\end{array}$ & No data available & 11,000 & No data available \\
\hline $\begin{array}{l}\text { Membership in } \\
\text { organisations, } \\
\text { (cooperation), } \\
\text { advertising }\end{array}$ & $\begin{array}{c}\text { Yes } \\
\text { Partner of the AUCHAN retail } \\
\text { chain }^{16} \text {, Member of the } \\
\text { Foundation for the Promotion of } \\
\text { Pork Meat (FPMWp }{ }^{17} \text { ); } \\
\text { Cooperation with: the National } \\
\text { Rural Development Network, } \\
\text { Online Slaughter Pigs Exchange } \\
\text { Platform e-WGT, the Modern } \\
\text { Farmer Portal 'farmer.pl' and } \\
\text { Wieprzopedia; it organises } \\
\text { exhibitions of farm animals }\end{array}$ & $\begin{array}{c}\text { Yes } \\
\text { Member of the International } \\
\text { Committee for Animal Recor } \\
\text { ding (ICAR), the World } \\
\text { Holstein Friesian Federation } \\
\text { (WHFF) and the European } \\
\text { Holstein and Red Holstein } \\
\text { Confederation (EHRC) }{ }^{18} \text {; it } \\
\text { organises exhibitions of } \\
\text { animals and runs an online } \\
\text { portal }\end{array}$ & $\begin{array}{c}\text { Yes } \\
\text { It runs its own online } \\
\text { portal } \\
\text { The Polish Sheep } \\
\text { Breeders' Association } \\
\text { was a co-author of the } \\
\text { 'Programme for } \\
\text { Improving The Sheep } \\
\text { Population by } 2010 \text { ' }\end{array}$ \\
\hline $\begin{array}{l}\text { Service activity } \\
\text { (e.g. keeping } \\
\text { flock books) }\end{array}$ & Yes & Yes $^{19}$ & $\mathrm{Yes}^{20}$ \\
\hline
\end{tabular}

Source: own elaboration.

The 1990s saw a large decline in the number of sheep caused mainly by low wool prices and the established quotas for export of slaughter lambs to the European Union. The Polish Sheep Breeders' Association was the initiator and participant of the teams working on rebuilding and development Programmes for the sheep industry. 'The Programme for

\footnotetext{
${ }^{16}$ In the cooperation program with AUCHAN in the field of the production of pork from pigs of the Puławska breed (conservative breed).

${ }^{17}$ The 'Strategy for Reconstruction and Development of Pork Production in Poland through 2030' was developed due to the funds of FPMWp.

${ }^{18}$ http://www.www.pfhb.pl/pages/uczestniczylismy

${ }^{19}$ PFHBiPM is responsible for keeping flock books for nine breeds of dairy cattle in Poland.

20 Since 1995, the Polish Sheep Breeders Association has carried out the evaluation of performance and has kept flock books for sheep and goats.
} 
Improving The Sheep Population by 2010' was approved by the Minister of Agriculture and Rural Development in 1996. The breeding objectives were changed, from the improvement of the wool characteristics to the improvement of the meat characteristics and reproductive performance of the entire sheep population. Since 1995, the Polish Sheep Breeders' Association has been evaluating the performance of sheep and goat and has kept flock-books for these animals.

In the description of the three tested organisations (Table 1), POLSUS clearly stands out. It has a long tradition of activity (more than sixty years) and is involved in activities for the benefit of producers and breeders of pigs (including the conservative breed 'Puławiak') through cooperation and promotion. The Federation of Cattle Breeders and Dairy Producers is also active, although its activity has been much shorter (since 1989). Against the backdrop of the two distinguished organisations, the Polish Sheep Breeders Association is an organisation with a long tradition, fulfilling its statutory purpose, more focused, with less diverse activities.

\section{The results of own research}

Knowing how to cooperate with external entities is a source of advantage on the market and a form of coordination (Latusek-Jurczak, 2011, p. 27). Thus, learning the context of the farm $\leftrightarrow$ environment system allows for the role of industry organisation in the network of connections to be assessed. Relationships with industry organisations allow farms to develop (through access to knowledge, facilitating the establishment of contact with recipients or the acquisition of public aid for investments and innovations).

The variables (characterising the studied relationships) adopted in the paper define their current state. The first characteristic (variable), quality, is a subjective measure expressing the respondent's opinion on their existing experience regarding the cooperation of farms with industry organisations. The high quality rate proves that the relationship is very good, regardless of the reasons behind it. Relationship quality can be due to sustainability, dependence, or uniqueness, which provided the context for further assessment.

The second variable is relationship sustainability, depending mostly on the duration of cooperation. The longer the relationship, the more sustainable it is. The power of dependence in a relationship between a breeder and an industrial organisation depends mostly on the competence of the organisation (or association). The more services (such as registering animals, signing sale contracts) the organisation can provide to the farmers, the greater the dependence. High dependence rating indicates a strong connection, not necessarily good relationships. According to B. de Wit and R. Meyer (2007, p. 224), the impact of the distribution of power on inter-organisational relationships may lead to four relationship types: mutual independence, unequal independence, interdependence, and unequal dependence. Dependence relationships in a network allow the participants to obtain a quasi-pension from the relation through cost reduction (Dyer, 1997, p.535-556). On the other hand, independence relationships are more beneficial when network partners do not need to maintain many relationships. For example, when products are standardised or cooperation is formalised, independence relationships stimulate organisational innovation.

Uniqueness is a very subjective relationship characteristic resulting for example from statutory conditions of membership of an industry organisation (assessment of rights, 
responsibilities, fees, possibilities of applying for aid from the organisation in emergency situations, etc.).

The results of the research carried out among representatives of industry organisations and farmers who are members of industry organisations, show the differences in the evaluation of quality, sustainability, interdependence and uniqueness of the relationships. This confirms the existence of a quality gap and the need to implement corrective actions (trainings, meetings, trips). As for the opinions of farmers, breeders of pigs and sheep rated the relationship the highest (Table 2), while cattle owners - the lowest.

A thorough analysis of the status of the relationships allows us to conclude that the best quality and sustainability was developed by pig breeders, with 'weak' uniqueness of these relationships (1 point), as the relationship with the union in terms of 'uniqueness' was not classified (0 points). The situation with the industry association POLSUS was quite different, as all the categories of relationships with farmers were rated very high (5 points). The remaining industry associations of cattle breeders (PFHBiPM) and sheep breeders (PZOw) also evaluated the quality and sustainability of relationships highly, but the uniqueness of the relationships with breeders was rated lower than in the case of POLSUS.

According to the author's interview, the working climate in the POLSUS association was family-friendly (clan-type relationships). The association's employees were satisfied with their cooperation with farmers and with one another in the office. In the author's opinion, the presence of the leader (an outstanding expert in the Puławska breed), supporting the cooperation of the association, evoked enthusiasm in the relationships. In the Polish Sheep Breeders' Association, the rating of the association was lower (more prudent) and the lowest score was given to the association (PFHBiPM), representing producers and cattle breeders.

Table 2. Evaluation of relationships between industry organisations and farms (farmers) with conservative breeds [1-5; with 5-max]

\begin{tabular}{|c|c|c|c|c|c|c|}
\hline \multirow{2}{*}{ Specification } & \multicolumn{2}{|c|}{ Cattle } & \multicolumn{2}{|c|}{ Pigs } & \multicolumn{2}{|c|}{ Sheep } \\
\hline & PFHBiPM & Farmer & POLSUS & Farmer & PZOw & Farmer \\
\hline Quality & 5 & 3 & 5 & 5 & 4,5 & 3 \\
\hline Sustainability & 5 & 3 & 5 & 5 & 5 & 4,5 \\
\hline $\begin{array}{l}\text { The power of } \\
\text { interdependence }\end{array}$ & 3 & 4 & 5 & 1 & 5 & 5 \\
\hline $\begin{array}{l}\text { Evaluation of } \\
\text { uniqueness of } \\
\text { relationships }\end{array}$ & 1 & 1 & 5 & 0 & 1 & 3 \\
\hline $\begin{array}{l}\text { What do good } \\
\text { relationships } \\
\text { mean? }\end{array}$ & Trust & $\begin{array}{l}\text { Trust; } \\
\text { maintained } \\
\text { relationships } \\
\text { give the } \\
\text { opportunity to } \\
\text { exchange new } \\
\text { information }\end{array}$ & $\begin{array}{l}\text { Continuous } \\
\text { collaboration }\end{array}$ & $\begin{array}{l}\text { Mutual } \\
\text { benefits }\end{array}$ & $\begin{array}{c}\text { Good } \\
\text { collaboration, } \\
\text { 'for the sake } \\
\text { of good } \\
\text { economy', } \\
\text { mutual } \\
\text { understanding }\end{array}$ & $\begin{array}{l}\text { They make } \\
\text { available the } \\
\text { exchange of } \\
\text { information, } \\
\text { timeliness }\end{array}$ \\
\hline
\end{tabular}

Source: own research.

In terms of dependence power, breeders networks and sheep associations were given the highest rating. In the remaining relations (cattle and pigs), the rates were uneven. The 
relation between POLSUS and the breeders was the weakest (rating: organisation -5 , breeder $0=$ no opinion). The weight of relationship ratings in the context of their durability (time from the establishment of industry organisations). The highest weights of ratings of relationships between industry organisations and breeders due to durability regard POLSUS and PZOw (since 1956). Thus, low ratings of the relationship with the PFHBiPM cattle breeders federation may be due to its shorter lifetime (since 1995) and less experience in cooperation with breeders.

As for the understanding of 'good relationships' by breeders and industry associations, PFHBiPM had the closest understanding, as it indicated 'trust' as the basis for good relationships. In the statements of POLSUS and PSBA, there was a greater divergence in understanding 'good relationships'. It is interesting that the aspect of economic benefits from the relationships with industry associations appeared solely in the opinions of employees of PSBA, and not the breeders. Sheep and cattle breeders agreed that 'proper exchange of information' is a common denominator of good relationships. One may conclude that in such relations, knowledge and information flow gain importance, so all sources of knowledge asymmetry should be eliminated.

\section{Conclusions}

Researching the relational premises in the cooperation between industry organisations and breeders provides many conclusions. The existence of cooperation and engagement fostering the studied relationships can surely be confirmed. The opinions of breeders of different animal species vary both in terms of relationship assessment (regarding quality, sustainability, uniqueness and dependence) and the meaning of "good relations".

The paper poses research questions as to whether industry organisations feel comfortable in the new role and support farms with conservative breeds of animals in order to put them on the path to development, and the answer to this question is in the affirmative. The history of activity of industry organisations confirms that they constantly take efforts to fulfil the needs of breeders/producers. Regardless of the political conditions, the organisations have tried to activate the farmer's environment to meet challenges, such as adjusting the production to EU requirements, entering foreign markets, and promotion. The current status of industry organisations is a result of effective actions with regard to the needs and challenges of the environment represented (e.g. maintaining biodiversity).

This is largely achieved through the soft skills of co-operating members of the network, the creation of platforms with the aim of exchanging views, consistent demonstration of the needs of members (farmers).

Analyses of industry organisations have confirmed their participation in activities which are important for affiliated farms, such as: cooperation with international organisations, evaluation of the value of animals, keeping flock books, representation, promotion, training. Preliminary studies show that the best conditions for cooperation for producers and breeders of conservative breeds of animals were created in the pig industry association (POLSUS). Good relationships in the network created by the POLSUS organisation and farms with conservative breeds are the result of continuous cooperation and mutual benefits. A thorough analysis suggests that lower relationship ratings could have been due to a shorter time of market operations of the cattle breeders association and better ratings were a result of longer cooperation. 
Within the assessment of relationship characteristics, a particularly unequal "dependence" between pig breeders and the association was discovered. The unionists rated it highly, contrary to farmers. This discrepancy may indicate that breeders do not take the association seriously. In contrast, the sheep breeders association rated the "dependence" in inter-organisational relationships highly. These rates do not affects the relationships negatively, but they indicate differences in the organisational cultures of the associations.

From the practical point of view, the power of "dependence" is created by the provisions of the industry organisations' statutes and the range of services provided to the farmers (keeping herd-books, guaranteeing sale contracts). In the case of the cattle association, relatively low dependence proves the independence of the association, which has limited abilities to "bind" breeders. Special attention should be paid to the development of the uniqueness of relationships between breeders and organisations. Changes in the practices regarding the atmosphere of cooperation and the development of actions supporting individual farms could shift the state of the relationships from slightly unique to unique. The problem of relationship uniqueness should be considered in future studies, specifying what unique relations (not only good relations) are.

It is also possible to conclude that industry organisations of supra-local nature play more important role in shaping contractual (formal) relationships and trade habits (contracting) than small organisations. Hence, nationwide (major) industry organisations mainly create conditions for integration of domestic producers and breeders. Recognizing the trend in the EU legislation (reinforcement of the position of agricultural producer organisations), efforts should be taken to empower industry organisations in order to increase their capacity to fulfil their role in the context of globalization and commercialization of agriculture $^{21}$ through engagement in solving problems not only pertaining to the entire industry, but also to individual $\operatorname{cases}^{22}$.

In the perspective of the research on economic relations of farmers representing the interests of biodiversity policy, it is useful to keep an eye on the opportunities and threats of the relationships and to seek ways to strengthen those relationships. The respondents' opinions on the meaning of "good relations" indicate that information and knowledge exchange is the key to success in this field. The flow of information in networks of breeders and industry organisations (in particular sheep and cattle) requires further research. Farmers expect assistance, while industry organisations - good cooperation. The development of tested relationship management techniques, as well as the development of a methodology for analysing transaction costs of such activities should be at the centre of both parties' interest.

\section{References}

Arrow, K.J. (1985). The Economic of Agency. In: Principals and Agents: The structure of Business W.J.W. Pratt, R.J. Zeckhauser (eds.). Harward Business School Press (pp. 54-74). Boston.

Balakrishnan, S., Koza, M. (1993). Information asymmetry, adverse selection and joint ventures: Theory and evidence. Journal of Economic Behavior and Organization, 20, 99-117.

Coase, R.H. (1988). The firm, the market, and the law, The University of Chicago Press, Chicago and London.

${ }^{21}$ Attempts are being made to oblige the private sector to cooperate with agricultural organizations. Currently, the private sector is exempted from the obligation.

${ }_{22}$ Currently, representation of the interests of individual farmers is legally restricted; the issue was raised by A.Sikorska-Lewandowska (2016, p. 175); hence, it is advisable, according to the author, to 'strengthen the position of agricultural producer organizations', as suggested by L.Russo (2014, p. 151). 
Cygler, J. (2007). Kooperencja przedsiębiorstw, czynniki sektorowe i kooperacyjne. Wyd. SGH, Warszawa. Cygler, J. (2002). Alianse strategiczne. Difin. Warszawa.

Czakon, W. (2007). Dynamika więzi międzyorganisacyjnych przedsiębiorstwa. Wyd. AE w Katowicach, Katowice.

Domagalska-Grędys, M. (2016). Mikro-konteksty kształtowania zmian relacji w sieci grup producentów rolnych. In: Zarządzanie współczesnym przedsiębiorstwem. Uwarunkowania. Trendy. Perspektywy, W. Sroka (ed.). Wyd. Tonik, Stowarzyszenie Wyższej Użyteczności „Dom Organisatora”, 293-308. Toruń.

Dyer, J.H. (1997). Effective Interfirm Collaboration: How Firm Minimize Transaction Value. Strategic Management Journal, 18(7), 535-556.

Grzybek, M. (2003). Dywersyfikacja instytucjonalnego otoczenia małych przedsiębiorstw w woj. podkarpackim, Zeszyty Naukowe UR w Rzeszowie. Seria Ekonomiczna. Ekonomika Rolnictwa, 1(9), 31-39.

Halamska, M. (2006). Tworzenie i praktykowanie demokracji lokalnej w Polsce. Wieś i Rolnictwo, 3, 9-25.

Halamska, M. (ed.) (2008). Wiejskie organisacje pozarzadowe. Wyd. IEiGŻ, Warszawa.

Kołodziejczyk, D., Wasilewski, A. (2005). Identyfikacja instytucji działających na obszarach wiejskich. Warszawa: IEiGŻ - PIB.

Kawa, M., Grzybek, M. (2009). Wpływ otoczenia instytucjonalnego na rozwój gospodarstw rolnych. Roczniki Naukowe SERiA, 11(5), 125-130.

Krupiński, J. (2008). Ochrona zasobów genetycznych zwierząt gospodarskich w Polsce. Wiadomości Zootechniczne, 1, 1-10.

Krzyżanowski, L. (1999). O podstawach kierowania organizacjami inaczej. PWE, Warszawa.

Latusek-Jurczak, D. (2010). Zarządzanie międzyorganizacyjne. Oficyna a Wolter Kluwer Business, Warszawa.

Latusek-Jurczak, D. (2011). Sieci międzyorganizacyjne jako struktury współpracy - podstawowe pojęcia analityczne. In: Relacje międzyorganizacyjne z naukach o zarządzaniu. A.K. Koźmiński, D. LatusekJurczak (eds.) Wyd. Oficyna a Wolters Kluwer business, Warszawa.

Lorenzoni, G., Lippari, A. (1999). The leveraging of interfirm relationships as a distinctive organisational capacity: a longitudinal study. Strategic Management Journal, 20, 317-338.

Milczarek-Andrzejewska, D., Śpiewak R. (2015). Organizacje rolnicze i ich wpływ na otoczenie-podejście teoretyczne z perspektywy socjologicznej i ekonomicznej. Wieś i Rolnictwo, 4(169), 67-76.

Miś, T. (2008). Otoczenie instytucjonalne rolnictwa. In: Rola lokalnych instytucji w przekształceniach rolnictwa o rozdrobnionej strukturze gospodarstw. A. Czudec, R. Kata, T. Miś, D. Zając (eds.) Wyd. Uniwersytetu Rzeszowskiego. Rzeszów.

Powell, W.W. (1990). Neither Market Nor Hierarchy: Network Forms of Organisation. Research in Organisational Behavior, 12, 295-336.

Sikorska-Lewandowska, A. (2016). Uprawnienia rolniczego zrzeszenia branżowego. Przeglad Prawa Rolnego, $1(18), 163-178$.

Ratajczak-Mrozek, M. (2009). Sieci biznesowe na tle innych koncepcji kooperacji przedsiębiorstw. Gospodarka Narodowa, 7-8, 79-91.

Russo, L. (2014). Reforma WPR z 2013 r. i stosunki umowne pomiędzy uczestnikami rynku. Przeglad Prawa Rolnego, 2, 151-173.

Williamson, O.E. (1998). Ekonomiczne instytucje kapitalizmu. PWN. Warszawa.

Wilkin, J. (2003). Peryferyjność i marginalizacja w świetle nowych teorii rozwoju (nowa geografia ekonomiczna, teoria wzrostu endogennego, instytucjonalizm). In: Regiony peryferyjne w perspektywie polityki strukturalnej Unii Europejskiej. A. Bołtromiuk (ed.) Wyd. Uniwersytetu w Białymstoku. Białystok. 45-46.

Wit de, B., Meyer, R. (2007). Synteza strategii, PWE. Warszawa.

Woźniak, M.G. (2009). Fundamentalne kwestie budowy spójności społeczno-ekonomicznej i gospodarki innowacyjnej w Polsce. Nierówności Spoleczne a Wzrost Gospodarczy, 15, 7-27

Wójtowicz-Dawid, A. (2011). Organizacje pozarządowe i ich rola w realizacji spójności społeczno-ekonomicznej - wybrane aspekty prawne. Nierówności Spoleczne a Wzrost Gospodarczy. 18, 335-345.

Online sources:

Package 7: "The Conservation of Endangered Genetic Resources of Animals in Agriculture" (description). Accessed 7 October 2017 from: http://www.arimr.gov.pl/fileadmin/pliki/PB_2015/WPRE/03_03_2017/PRSK_2017_ Pakiet 7.pdf.

POLSUS (the website of the association and its organisational structure). Accessed 7 October 2017 from: http://www.polsus.pl/kontakt/filie i http://www.polsus.pl/o-nas/struktura.

The ordinance of the Ministry of Agriculture and Rural Development of 18 March 2015 on detailed conditions and procedure for granting financial aid under the 'Agri-environmental and Climatic Measure' within the Rural Development Programme for the years 2014-2020. Accessed 7 October 2017 from: http://www.arimr.gov.pl/fileadmin/pliki/PB_2015/WPRE/16_03_2017/D20150415.pdf. 